\title{
A Educação Matemática Muda
}

\author{
Mathematics Education Changes
}

Filipe Santos Fernandes*

\begin{abstract}
Resumo
Um famoso linguista foi desafiado, certa vez, a gramaticar um livro de páginas infinitas. Guiado pela palavra "muda", o homem diz de uma Educação Matemática desenhando-se em três sentidos: o do substantivo, o do verbo e o do adjetivo. Desenhos inacabados, rascunhos de um caderno desesperadamente construído. Entre narrativas e produções de sentido, um pensar a efetividade de uma prática social, a Educação Matemática.
\end{abstract}

Palavras-chave: Educação Matemática. Narrativa. Prática Social.

\begin{abstract}
Once a famous linguistic was challenged to grammarize a book of endless pages. Led by the word "change", the man talk about Mathematics Education drawing three senses: the one of the noun, the one of the verb and the one of the adjective. Unfinished drawings, drafts of a notebook built in a hopeless manner. Between narratives and productions of meaning, thinking of affection of a social practice, the Mathematics Education.
\end{abstract}

Keywords: Mathematics Education. Narrative. Social Practice.

\section{Abertura}

"A linha consta de um número infinito de pontos; o plano, de um número infinito de linhas; o volume, de um número infinito de planos; o hipervolume, de um número infinito de volumes... Não, decididamente não é este, more geométrico, o melhor modo de iniciar o meu relato. Afirmar que é verídico é, agora, uma convenção do relato fantástico; o meu, no entanto, é verídico." - Afirmava ele, incessantemente."

\footnotetext{
* Doutor em Educação Matemática pela Universidade Estadual Paulista "Júlio de Mesquita Filho"/UNESP. Professor da Faculdade de Educação da Universidade Federal de Minas Gerais/UFMG, Belo Horizonte, Minas Gerais, Brasil. Membro do Grupo de Pesquisa História Oral e Educação Matemática/GHOEM da Universidade Estadual Paulista "Júlio de Mesquita Filho"/UNESP, Rio Claro/SP. Endereço para correspondência: Rua dos Aeroviários, 321, Pampulha, Belo Horizonte/MG, Brasil, CEP. 36030-230. E-mail: fernandes.fjf@gmail.com.

${ }^{* *}$ Os trechos em itálico que compõem a primeira parte deste texto foram retirados do conto $O$ livro de areia, de Jorge Luis Borges (2009).
} 
Para tratar da existência de uma prática de pesquisa em Educação Matemática - que revela, sobremaneira, a emergência de uma comunidade científica, em seus aspectos de constituição e consolidação no cenário científico-acadêmico -, Miguel et al. (2004) comentam que “a Educação Matemática é uma prática social que não está ainda nem topologicamente diferenciada das demais no interior do espaço acadêmico, nem juridicamente estabelecida como campo profissional autônomo, nem, portanto, institucionalmente reconhecida como campo disciplinar" (MIGUEL et al., 2004, p. 81).

A prática social é, segundo os autores, compreendida como um conjunto de conjuntos composto por quatro elementos: "1) por uma comunidade humana ou conjunto de pessoas; 2) por um conjunto de ações realizadas por essas pessoas em um espaço e tempo determinados; 3) por um conjunto de finalidades orientadoras de tais ações; 4) por um conjunto de conhecimentos produzidos por tal comunidade" (MIGUEL et al., 2004, p. 82). Nesse cenário em que a Educação Matemática é entendida como um complexo processo em possíveis vias de disciplinarização ${ }^{1}$, o educador matemático percebe-se em formas mais abrangentes em relação ao campo em que se situa, podendo, inclusive, pertencer topologicamente a áreas já constituídas como campos disciplinares ${ }^{2}$.

Garnica (2008), ao defender essa perspectiva para a Educação Matemática, destaca que, mesmo que não haja uma pretensão de disciplinarização por parte da comunidade, o que implicaria posturas teórico-metodológicas mais específicas e menos flexíveis, devemos nos esforçar na problematização dos nossos fundantes epistemológicos, colocando-os em suspeita e permitindo, no limite, formular princípios inegociáveis pelos quais estabeleceríamos nossas relações com outras áreas de pesquisa - as parcerias, as negociações, as aproximações teóricas

\footnotetext{
${ }^{1}$ Miguel et al. (2004) tomam a palavra disciplinarização em uma associação com a noção de disciplina de Chervel, de modo que a palavra não se restringe a uma matéria escolar ou acadêmica, mas a "um campo autônomo de investigação e de formação profissional institucionalmente legitimado, topologicamente diferenciado no interior do espaço acadêmico e juridicamente estabelecido como campo profissional autônomo" (MIGUEL et al., 2004, p. 82). Assim, por disciplinarização entende-se o complexo processo de constituição de uma disciplina a partir de uma prática social.

${ }^{2}$ Nas compreensões de Miguel et al. (2004), entende-se a comunidade de educadores matemáticos como sendo constituída por: "[...] professores de matemática que não pesquisam suas práticas e que não veem com bons olhos os pesquisadores acadêmicos em educação matemática; pesquisadores acadêmicos em matemática e em educação que participam da formação desses professores, mas que não gostam muito de fazer isso e, se pudessem, não o fariam; de matemáticos que não pesquisam nem matemática e nem educação, mas que formam, a gosto ou a contragosto, professores de matemática; pesquisadores matemáticos que gostariam de fazer educação matemática, mas que se acham impedidos de fazer o que desejariam fazer; pedagogos e psicólogos, por alguns considerados matematicamente incultos, mas que realizam pesquisas em educação matemática; matemáticos conteudistas de última hora, moralizadores, arrogantes e inflexíveis, que se imaginam salvadores da pátria e legítimos proprietários e defensores do nível e do rigor da educação matemática da população; mas também por professores de matemática, pesquisadores em matemática, pesquisadores em educação matemática e outros profissionais que fazem e acreditam na educação matemática e tentam, de fato, levar a sério o que fazem." (p. 89)
} 
e metodológicas, o gerenciamento de nossos embates. Essa defesa sustenta-se em duas posições, fundamentalmente: uma necessidade política da comunidade em autorregular-se e o investimento em esforços para compreensão de quais são e como operam nossas concepções de conhecimento.

Pensar a Educação Matemática como prática social significa, pois, compreendê-la para além do âmbito de normatizações que regulamentam ações profissionais e de pesquisa, mas em um cenário de constante problematização de normatizações, sempre provisórias, que se compõe junto a essas ações profissionais e de pesquisa. Nesse aspecto, a Educação Matemática não é anterior às relações que se estabelecem, mas junto a elas, no constante processo de se fazer.

Seria mesmo ingênuo acreditar que uma prática social na qual convivem tantos profissionais de diferentes contextos de atuação, pudesse, em um tão curto espaço de tempo, constituir regulações e princípios norteadores de práticas que nela são mobilizadas. [...] Penso que os terrenos, fronteiras, lugares da Educação Matemática se institucionalizam de maneira complexa e que talvez, não se ajustem aos critérios clássicos de demarcações de ciência ou campo de conhecimento científico (VIOLA DOS SANTOS, 2012, p. 13).

A Educação Matemática situa-se, quando pensada junto a essa discussão, além das epistemologias que postulam a dissociabilidade do conhecimento daquele que conhece. Entendida como "atividades sociais realizadas por um conjunto de indivíduos que produzem conhecimentos, e não apenas ao conjunto de conhecimentos produzidos por esses indivíduos em suas atividades" (MIGUEL et al., 2004, p. 82), a Educação Matemática passa a subverter essas noções epistemológicas, colocando em cena outras epistemologias - um convite para a produção de um modo diverso de compreender o conhecimento.

De tal modo, não se trataria apenas de pensar como os sujeitos produzem uma prática social, conforme um processo canônico de produção, mas sim como, em sua configuração, essa prática social promove a produção de subjetividades. As práticas sociais podem, por um lado, ser pensadas como produtos: formas estriadas - uma comunidade, por exemplo - que possuem objetivos e afinidades - sejam elas científicas, epistemológicas, culturais, físicas em torno de uma finalidade específica. Inevitavelmente, porém e por outro, essa prática social é submetida aos agentes que a produzem e, tal como que, em seu avesso, ela é processo: em seu liso, configuram-se novos modos de existir - novas comunidades, novos conceitos, novos valores, novas finalidades, ações, condições espaço-temporais, subjetividades. A produção de subjetividades promovida pela prática social é também sua produtora: o entrelaçamento é o que interessa a este texto, a indissociabilidade, o "sem antes e sem depois". 
Essa compreensão reforça a ideia de que a Educação Matemática, apesar de possuir contornos mais definidos em um âmbito social, constituindo-se como uma prática social historicamente situada e socialmente legitimada por um grupo que diz produzir pesquisa, ainda não apresenta estabilizações no campo filosófico quando considerada em várias de suas dimensões - epistemológicas, políticas, estéticas, éticas. Assim, a problematização "que ciência é a Educação Matemática?”, fundamentada no fato de não existir - ou na não aparente existência de um consenso referente, por exemplo, a correntes de pensamento, paradigmas de investigação, métodos, processos, critérios de legitimação, de qualidade, de validação dos resultados, cria um espaço em que a problematização dessa prática social é sempre estabelecida em um caráter quase efêmero que não suporta a longevidade se tomado em sua invariabilidade.

Dito isso, coloca-se como tarefa fundamental para aqueles que assumem tal prática social a problematização dos fundantes e a exploração dos limites dessas fundamentações. Nessas problemáticas e nesses limites, modos distintos da Educação Matemática passam a operar. Contudo, como dar expressão aos modos, às formas, aos rascunhos de uma prática social? Talvez, uma linguagem outra, que escapa do habitual no cenário acadêmico, possa potencializar essa expressão...

\section{Parte primeira: o linguista, o livro infinito e a gramática}

Nessa época, já tinha um importante nome firmado entre os linguistas. Havia assinado mais de vinte livros e publicado tantos textos que sequer se lembrava dos títulos. Um deles, traduzido para oito ou mais línguas, era de leitura obrigatória para os profissionais da área em boa parte do mundo. Um livro complexo que, na arrogância de muitos professores, era usado nos primeiros anos da graduação, mas entendido sequer pelos brilhantes doutores da área. Viajava o mundo. Era solicitado, admirado, respeitado e aplaudido. Tinha um sobrenome que era antes dele.

Após uma aula exaustiva, em que o tema era justamente um dos tópicos do livro tratado, voltou para sua sala e encontrou à porta um pacote embrulhado de um jeito apressado em papel pardo e barbante. Sem remetente, endereço, destinatário ou assunto, havia na parte de baixo, que há pouco tocava o solo, a frase escrita à mão: "Gramatique-me".

Achou estranho, mas sua curiosidade foi maior. Entrou na sala, deixou o renomado livro em um canto de uma mesa bagunçada e abriu o envelope. Nele, um livro. Tomou novamente o papel pardo. "Gramatique-me?" - indagava-se com um leve sorriso de quem se 
encontra com um curioso mistério. Infelizmente não teria tempo para ler aquelas páginas naquele dia. Era véspera de um evento em Praga para o qual lhe haviam encomendado a conferência de abertura. Meteu o pequeno livro dentro de sua bolsa na esperança de que, naquela viagem, pudesse lê-lo.

Um velho livro como qualquer outro livro velho. Capa dura com encadernação preta e levemente puída nos cantos, castigo do tempo. Um livro não tão grande, nem tão pequeno: perfeitamente acomodável no encaixe das mãos, mas com laudas suficientes para causar incômodo a qualquer adolescente avesso à leitura. Nem tão leve, nem tão pesado: serviria perfeitamente como peso para uma pilha de papel, mas fracassaria na tarefa de segurar uma porta exposta ao vento. No centro superior, letras de um dourado esmaecido anunciavam um tema: "A Educação Matemática Muda". O bordado das letras, acompanhadas das linhas de tons dourados que contornavam a capa do livro, denunciam certo ar de rebuscamento e soberba: rebuscado no tom barroco que quase se entregava a um questionável rococó; soberbo em seu tom aristocrático, restrito e alegórico.

Estranhamente, em nenhum lugar do livro encontrava o nome de um autor ou organizador, tampouco esses termos no plural. Contudo, não cogitou - mesmo que num instante inicial, num lapso de pensamento tão rápido quanto a esquiva do olhar - a hipótese de um livro sem autoria. Em nenhum lugar encontrava a editora, o ano ou o lugar de origem. Parecia nascido do nada, o livro, e para o nada convertido.

Resolveu, então, abri-lo. As páginas, que me pareceram gastas e de pobre tipografia, estavam impressas em duas colunas. Chamou a atenção que a página par trouxesse o número (digamos) 40.5014 e a ímpar, a seguinte, 999. Sentiu-se incomodado. Nem mesmo em pares as páginas se organizavam. Apoiou a mão esquerda sobre a portada e abriu o livro com o dedo polegar quase pegado ao indicador. Tudo foi inútil: sempre se interpunham várias folhas entre a portada e a mão. Era como se brotassem do livro. Outro incômodo: infinito era o número de páginas. Cada vez que o abria, uma nova página aparecia. Assumiu esse desconcerto. "Não pode ser, mas é. O número de páginas deste livro é exatamente infinito. Nenhuma é a primeira; nenhuma, a última. Não sei por que estão numeradas desse modo arbitrário", pensava. Resolveu iniciar uma leitura ao acaso, sem se prender à mesmice da enumerabilidade. 
Sentia-se impotente na travessura que havia assumido em dias anteriores. Afinal, deveria ele gramaticar um livro? A obsessão tornava longas as noites... A mão, ao tomar para si a xícara de café que já compunha a estrutura da mesa, tremia a ponto de imprimir na superfície do líquido uma geometria de ondulações. Tampouco percebia isso. Seu olhar voltava-se intensamente para o livro.

Praga nunca foi para ele uma cidade encantadora. No entanto, ele ali estava, diante de enorme plateia, com algumas poucas folhas para orientar sua fala e pequenos fragmentos expostos em uma projeção. $\mathrm{O}$ assunto era tão naturalizado que a palestra terminou sem qualquer dificuldade. Pensava, enquanto falava, na conta que havia esquecido de pagar e deixado sobre a escrivaninha da universidade; na possibilidade de antecipar seu voo; na menina que desenhava algo em um pedaço de papel e que despertava mais sua atenção que aquele emaranhado de palavras que lia e comentava.

Ao final, depois de empolgados aplausos, abriu-se a sessão de perguntas. Um jovem com certo ar prepotente aponta um equívoco em sua fala. Desinteressado, respondeu com uma simples piada. Meia dúzia de respostas óbvias passam, até que uma jovem pede a palavra. Ao levantar-se, pergunta: "Professor, o que faz uma palavra pegar delírio?" Todos riem, exceto ele. Inexplicavelmente, aquela pergunta parecia ser a mais sensata da ocasião. Ele, em um minuto que parecia uma eternidade, olha hipnotizado para a jovem: naquele momento, não conseguiria expressar qualquer contestação. As risadas param, e o incômodo silêncio que dura alguns minutos é quebrado com sua resposta: "Obrigado!"

Naquele momento, lembrou-se de Manoel de Barros. Ao pé do ouvido, uma voz parecia sussurrar versos:

\section{Veja que bugre só pega por desvios, não anda em} estradas -

Pois é nos desvios que encontra as melhores surpresas e os araticuns maduros.

Há que apenas saber errar bem o seu idioma. ${ }^{3}$

Correu para o hotel. Maior que a estranheza pela infinitude do livro era aquela causada pela pergunta daquela jovem. Pela primeira vez conseguia desenhar uma fagulha de entendimento: talvez não se tratasse de gramaticar o livro, mas de estabelecer a relação entre a Educação Matemática e a palavra muda. Tomou rapidamente um papel e rabiscou palavras:

\footnotetext{
${ }^{3}$ Manoel de Barros (2010, p. 319).
} 
muda, delírio. Pensou mais um pouco e, abaixo, acrescentou: substantivo, verbo, adjetivo. Talvez, nisso, a chave do seu mistério. De que modos muda pode gramaticalmente operar? Quais as reverberações disso para pensar a Educação Matemática?

Parecia, então, encontrar um caminho. Um caminho que, sabia, a nada poderia levar, mas que merecia ser percorrido. Um caminho em que mobilizaria ao máximo o que tinha em relação com o que lhe ofertavam: uma gramática e um livro infinito; uma estrutura de funcionamento em relação com um grupo infinito de fragmentos e vozes. Leu umas tantas páginas, por muito tempo. Leu mais algumas. Em meio às leituras, rabiscava desesperadamente um caderno de rascunhos. "E se aquelas páginas não voltassem”, pensava temoroso. Arriscou, por fim, uma proposta...

\begin{abstract}
Muda (substantivo feminino). Ato ou efeito de mudar ou mudar-se. Deslocação ou transferência de um sítio para outro. Renovação da pena (nas aves), da pele ou do pelo (em certos animais). Época em que essa renovação acontece. Substituição de cavalos ou muares cansados por outros folgados e colocados de distância a distância. Lugar onde se faz essa substituição. Mudança de voz que acontece na adolescência. Planta tirada do viveiro para plantação definitiva. Conjunto de peças de roupa para alguém poder mudar de vestuário.
\end{abstract}

Substantivos são entes gramaticais que, mediante um conjunto de atribuições, nomeiam coisas em geral. Um substantivo pode ser visto, pode ser pego ou pode ser sentido. Algo é substantivo quando concerne à substância, ao substancioso, ao substancial. Substantivo é aquilo que tem forma, mesmo que abstrata. Essa era a posição que defendia e com a qual pretendia seguir.

Se muda pode operar como substantivo, a Educação Matemática também pode. Pode? $\mathrm{Na}$ medida em que se define em uma substância, em algo que a determina, a Educação Matemática opera como nome. Ela pode ser vista, pode ser pega, pode ser sentida e, por isso, tem forma. Uma forma que ganha contornos no conjunto das atribuições que nomeia. Afinal, em um trecho do livro, lia-se que era preciso "investir em um corpo de Educação Matemática". Um corpo tão materializado e formado que permitiria, ainda, dizer que "nos sentíamos dentro da Educação Matemática que vinha nascendo", e crescia... Um corpo que crescia: "a Educação Matemática é muito adolescente".

Pensou, primeiro, a Educação Matemática como um substantivo comum: ela designaria entes de um mesmo grupo de forma genérica. Assim, à Educação Matemática competiria a tarefa de englobar vários outros nomes. Não foi difícil mostrar que isso 
acontecia. Ao folhear o livro infinito, lia expressões como "projetos vinculados à Educação Matemática" ou "as áreas da Educação Matemática". Estava convencido de sua classificação. Por várias vezes, lia na Educação Matemática um estatuto de totalidade, de forma definida, de consistência sólida que permitiria ramificações, tal como o sólido tronco de uma árvore que sustenta cada um de seus galhos e ramos, apoiando e alimentando.

Contudo, folheando o livro, dias depois, leu: "uma discussão que está sempre presente pra quem trabalha com uma especificidade, para quem está na Educação Matemática”. Ora, aqui, a Educação Matemática parecia operar de outro modo: deixava de ser um substantivo comum para se tornar um substantivo próprio; ela denomina entes de um mesmo grupo não de forma genérica, mas de forma particular. A Educação Matemática, como especificidade, reduzia-se à particularidade de algo. "De que algo?", perguntava-se. Também não sabia responder... A Educação Matemática parecia um pequeno e longínquo ramo de uma árvore desconhecida.

Buscou, então, outras classificações. Seguiu com a ideia da Educação Matemática como um substantivo concreto, afinal, encontrava no livro aqueles que diziam dela em suas realidades ou em seus imaginários. "Eu podia com isso fazer Educação Matemática", dizia alguém em um fragmento de texto. Parecia que a Educação Matemática, assim como o barro, poderia ser modelada, desenhada, esculpida. Mas também encontrou momentos em que a Educação Matemática perdia sua concretude para designar estados, qualidades, ações parecia que, por vezes, uma abstração se mantinha no modo como operava. Lembrava-se, então, de ter lido: “minha pesquisa em Educação Matemática está parada". Uma expressão que, para além da categorização da palavra, fazia com que a Educação Matemática só pudesse operar em seus estados ou ações. Havia algo que nomeava - a Educação Matemática, uma substância, um nome -, mas que só fazia sentido quando atribuída a um estado, a um movimento. Era como um pensamento distante; aquele que ainda não tem corpo, voz ou forma, mas que existe nas searas da imaginação.

Também tentou descrevê-la como substantivo coletivo. "Esse cara é do grupo da Educação Matemática", "o trabalho que você faz é que vai caracterizar você como alguém mais perto desse ou daquele grupo ou daquela comunidade" - lia. Contudo, atentou para o fato de que essa condição, essa possibilidade de ser um substantivo coletivo, era ambígua por ser "boa", na medida em que "permite conhecer vários segmentos, vários grupos", e "ruim", "porque você, em alguma medida, sofre algum tipo de rejeição por não ser do grupo". Perguntava-se se não encontraria, dada a infinitude do livro, outros momentos em que essa condição de coletividade era vista negativamente, a ponto de poder ser negada. Não existiria, 
na imensidão de fragmentos, textos e imagens, algo que se poderia dizer da Educação Matemática, mas que se nega a um coletivo "Educação Matemática"? Havia, porém, "forasteiros".

Optou por não arriscar: abandonou essa tentativa de classificação. Estranhamente, a Educação Matemática parecia, a um mesmo tempo, ter e não ter uma substância construída de modo que pudesse associar sua condição de palavra a um conjunto de coisas. As "coisas" pareciam, por vezes, escapar. Suspeitava ser isso tudo fruto de sua incapacidade. Afinal, como dar expressão à substância de algo que pode ser escrito em um livro infinito? Como dimensionar, separar, reunir ou limitar um conjunto de coisas para a atribuição de um nome quando essas coisas não podem ser vistas em sua totalidade? Enfim, como nomeá-las?

Muda (flexão do verbo mudar). Fazer ou sofrer alteração. Variar de habitação ou residência. Tirar de um lugar ou posição para outro. Substituir, trocar. Dispor ou apresentar-se de outra forma. Dar uma orientação, direção ou sentido. Estar na muda (da pena, da pele etc.). Cambiar, variar.

Parecia tarefa árdua fazer a Educação Matemática operar como um verbo. Verbos são essas palavras fundamentais que dizem de ações, estados ou de fenômenos da natureza; e nada disso parecia condizer com a Educação Matemática. Contudo, a impossibilidade de um substantivo e sua angústia com o livro motivaram-no a aventurar-se por esse caminho.

Muitas vezes a Educação Matemática mostrava-se como ação, sempre em movimento, marcando um antes e um depois, uma passagem que definia estados. "Depois que eu me instalo e vou para a Educação Matemática", "porque não estava na Educação Matemática", "eu me aproximei da Educação Matemática" - marcas de uma Educação Matemática que atua em um sentido de mudança. Mas, o que muda? Mudam-se estados, questões, significações, sentidos. Se isso muda, muda também a Educação Matemática: é outra e é mesma. Uma ação que não se faz antes, mas que se mantém no caminho: “ela vai se fazendo pela própria trajetória", leu.

Tentou conjugar esse verbo. Viu-se no fragmento do livro que parecia com ele falar, encontrando em meio às "circunstâncias que a gente vai conversando" algumas "pessoas que nos dizem”. Pessoas que vão modificando esse verbo, submetendo-o a variadas condições de estados. E volta a voz que parecia falar: "a história de vida das pessoas, de qualquer pessoa" "é uma história que está presente". Aqui, a insinuação de um tempo: o presente. E os outros 
tempos? Como conjugar a Educação Matemática em pretéritos e futuros? Parecia não saber, mesmo mantendo a certeza de que "esses trânsitos são, então, necessários".

Se a Educação Matemática é verbo, ela pode ser tomada no infinitivo. Antes do "eu como", o "comer": dimensão sem sujeito, sem tempo ou espaço. Mas, para tomar forma, a Educação Matemática precisa reunir elementos: "o sujeito que come tal comida, em tal espaço, em tal companhia, em...”. Uma reunião que só faz sentido nas conexões, nas variações, nas alianças e, também, nos desvios e negações. Aqui, talvez, a materialidade do verbo, sua possibilidade: a Educação Matemática só se faz como circunstância, como um modo de existir que se faz no $e-\mathrm{o}$ sujeito $e$ o espaço $e$ o tempo $e$ isso $e$ aquilo $e$... Parece tratar-se de uma prática eternamente fixada na "construção de uma prática".

Essa discussão trouxe a lembrança de um seminário que proferiu sobre a participação dos verbos na construção de metáforas e metonímias. As metáforas sempre lhe causaram receio: sua função, parecia a ele, era atribuir apenas uma equivalência de significados, de características comuns. Já metonímias lhe pareciam mais agradáveis: dizem não de uma semelhança de formas, mas de funcionamentos. Se a metáfora condensa, a metonímia desloca. É como quando se "chega de uma trajetória diferente em um lugar onde as pessoas muitas vezes já têm o seu hábito"; como estar entre o condensado e a possibilidade de deslocamento.

Por um lado, a Educação Matemática, verbo de construção de metáforas, segue estratificando sentidos. Ela, em suas afinidades semânticas com o verbo ser, vai definindo o que é: não era, era; não sou, sou. Ainda mudanças, mas mudanças que firmam estados sólidos, de determinações possíveis. Relações que conservam as características comuns, as aproximações, as similaridades. Por outro lado, a Educação Matemática, quando verbo de construção de metonímias, vai definhando sentidos, problematizando o que é. As mudanças, sem determinações, revelam nuances de acasos e necessidades. Não se trata de mudar por uma causa e um efeito, mas de, na dinâmica das necessidades da vida, nas possibilidades de engendrar nosso desejo ao desejo do acontecimento, tomar decisões e seguir, sem antes ou depois. O fundamental estava, pois, na passagem. Lembrou-se outra vez de Manoel de Barros:

No descomeço era o verbo.

Só depois é que veio o delírio do verbo.

O delírio do verbo estava no começo, lá onde a

criança diz: Eu escuto a cor dos passarinhos.

A criança não sabe que o verbo escutar não funciona

para cor, mas para som.

Então se a criança muda a função de um verbo, ele

delira.

E pois.

Em poesia que é voz de poeta, que é a voz de fazer 
nascimentos -

$O$ verbo tem que pegar delírio. ${ }^{4}$

Delirava tanto quando seus verbos. Tentou classificar a Educação Matemática em outras dinâmicas da dinâmica imposta pela gramática, mas não conseguia. Não entendia, por exemplo, se a Educação Matemática operaria de modo impessoal ou se, no caso pessoal, sofreria variações de pessoa a pessoa. Não sabia se poderia classificá-la como unipessoal, atribuída apenas a um conjunto de seres, como é o coaxar para os sapos ou o cricrilar para os grilos. Não sabia tampouco sobre sua regularidade. A insegurança de um continuar fazia-se cada vez mais presente.

Muda (adjetivo). Que não tem uso da palavra oral ou da capacidade de falar. Que não fala muito. Que não é acompanhado de palavras orais ou de grifos. Que não pronuncia ou que não se articula. Que não se manifesta abertamente. Em que não se ouve ruído algum.

Uma Educação Matemática muda. Uma Educação Matemática operando junto à impossibilidade de voz, ao silêncio, ao vazio. Educação Matemática que se cala ou que é calada, de pensamento indomado e sem linguagem própria ou adquirida. Vias de se fazer sem formas de expressão ou em formas de expressão não convencionais. Segredo, sigilo, silêncio.

Tomava em suas mãos o livro. Naquelas páginas, formas de expressão. Tudo parecia dito, contado, narrado. Ainda que intrigante a infinitude do livro, tudo parecia perfeitamente e sequencialmente encaixado. Não parecia haver espaços para vazios, para silêncios, para brancos. Até se dar conta de que o vazio não necessita de espaço, que o silêncio não necessita de voz e que o branco não necessita do negro. Tratava-se de buscar hiatos.

Por várias vezes, o silêncio, o sem voz, o não dobrado pela linguagem, são atribuídos ao acaso. É esse estranho componente de nossa vida que dá expressão aos desvios, às inconsistências, às incompreensões. "Algo interessante, talvez por essas coisas do acaso", do inesperado, do que não tem causa. "De novo o acaso", aquilo que insiste em existir para além de nossos desejos. Nos acasos habita tudo aquilo que não entendemos como motivos de nossos movimentos: a saudade, os conflitos, os interesses, as angústias, as inseguranças, os medos, os segredos... Tudo que é mesquinho, que é baixo, que é inconfessável.

\footnotetext{
${ }^{4}$ Manoel de Barros (2010, p. 101).
} 
Outras vezes, a mudez se expressa com o tecido do acidente. Um acidente que "mostrou que havia vida fora" ou que "a vida segue". Quando o acidente é, contudo, sentido, percebido, antecipado, ele pode ser evitado, mantendo-nos no fluxo de nosso desejo em meio às circunstâncias que nos cabem. "Foi quase um acidente isso", diria um pequeno pedaço de texto em que o desejo se mantinha na quase impossibilidade. E, nesse seguir, a vida vai "empurrando mais ou menos para um canto", sendo cada um de nós "levado para isso". Vai brincando de seguir cegamente, falando em silêncios e escrevendo com brancos: são, pois, "sentidos difíceis de serem explicitados".

Lembrou-se da única imagem que viu no livro - infinitas poderiam existir; para ele coube ver apenas uma. Um ovo, um homem com uma espada, uma lareira de fogo alto, um bem desenhado ambiente. Aquela imagem dizia tanto quanto uma escrita. Talvez aquela imagem só dissesse na impossibilidade do dizer escrito. A centralidade parecia estar no ovo: uma vida-ovo. Não uma vida em dois momentos, um antes e um depois do ovo, mas uma vida que insiste em verter-se ovo, que exige renascimento, exige constantemente novas origens, novos modos de existência, novas histórias. O homem impiedoso com a espada: uma figura do acaso. Sem compaixão, clemência ou perdão, o homem ataca, destrói, quebra, rompe. Desvia caminhos para uma nova vida; quebra cascas para um novo começo, para uma nova aventura, para outras formas. Um algo que nos remete "à travessia, transformação".

A Educação Matemática parece falar e, nisso, instaurar silêncios. A mudez não é apenas uma necessidade, mas uma condição. No acaso não há espaço, não há voz, não há palavra: não há nisso problema algum. A questão que enfrentava era a de como habitar um não-espaço, escutar o silêncio ou ler uma página em branco. $\mathrm{O}$ adjetivo se tornava cada vez mais impotente.

\section{Parte segunda: o caderno de rascunhos}

Em poucas horas percebera que as páginas do livro, infinitas, poderiam limitar seu trabalho. "Como vou encontrar mais uma vez uma página já lida em um livro tão peculiar?", pensava. A impossibilidade de revisitar um mesmo texto levou-o a um caderno de rascunhos. Nele, fragmentos, desassociados e inacabados. Textos de textos que disparavam questões, problemas e que, em sua totalidade provisória, permitiam produzir sentidos...

Página 32. "O que eu percebo é como, institucionalmente, a Educação Matemática é muito adolescente comparada com sua irmã Educação em Ciências. Nós éramos mais organizados! Só agora, 
de pouco tempo para cá, estamos ficando um pouco mais organizados novamente, mas eles já deram outro salto na nossa frente. E são irmãos! Não é competição, mas é olhar e aprender."

Página 2023. "Em um desses encontros, 1983, foi anunciado, pela Professora Maria Laura Leite Lopes, coordenadora de diversos projetos vinculados à Educação Matemática na UFRJ, que a Unesp estaria iniciando um curso de Mestrado em Educação Matemática.”

Página 109. "Enfim, essa é uma discussão que está sempre presente pra quem trabalha com uma especificidade, para quem está na Educação Matemática. Por exemplo, a gente está sempre se perguntando, sempre discutindo; e é bom que isso seja sempre perguntado: "Qual o sentido desse trabalho?". Não é o sentido prático, utilitário. São sentidos difíceis de serem explicitados, dependendo da plateia, do público... Mas você tem um sentido e precisa fazer sempre essa discussão. Agora, eu acho que esses diferentes temas, essas diferentes perspectivas da Educação Matemática, elas têm tido bastante desenvolvimento. As pesquisas, as pessoas... Cada vez fica, me parece, mais claro que contribuições são essas, que tipos de pesquisas são essas."

Página 52.110. "Eu lidava muito com as aulas particulares dessa maneira, sempre que podia. Inclusive, por questões financeiras, mas também por certo gosto, para o aluno que chegava desesperado em novembro, cobrava um preço $x$. Depois eu cobrava $x$ sobre três se ele viesse em março ou abril. Era também financeiro, mas eu podia com isso fazer Educação Matemática; e nem sei se eu já tinha essa expressão na minha cabeça em 1982.”

Página 7.863. "Atualmente, minha pesquisa em Educação Matemática está parada, não há outro jeito."

Página 5. "Mas acho que também por força disso; quer dizer, você não é da turma inicial: você é um forasteiro! Mas, na verdade, é uma trajetória que você pode virar forasteiro em qualquer lugar que você vai. Porque quando eu fui para a Educação, eu também era um forasteiro, porque eu era engenheiro e fui parar lá. Depois que eu me instalo e vou para a Educação Matemática, também sou um forasteiro, porque não estava na Educação Matemática. Essa condição é boa e ruim: boa porque permite conhecer vários segmentos, vários grupos; e ruim porque você, em alguma medida, sofre algum tipo de rejeição por não ser do grupo. Mas eu acho também que não quero isso: "Ah, esse cara é do grupo da Educação Matemática. Esse cara é do grupo da Educação. Ele é do ensino de...". Olha, acho que podemos ser reconhecidos pelo trabalho que a gente faz, e não, digamos assim, do ponto de partida da comunidade à qual se pertence. Acho que o trabalho que você faz é que vai caracterizar você como alguém mais perto desse ou daquele grupo ou daquela comunidade."

Página 501.231.771. “[...] fiquei sabendo do curso em Educação Matemática e nele comecei a trabalhar. A minha proximidade primeira é com a Educação, depois é que eu me aproximei da Educação Matemática."

Página 40. "Naquele tempo, certamente, não existiria concurso para História da Educação Matemática. Também acho que meu perfil não era adequado para as demandas desses poucos concursos. E a história do desenvolvimento profissional, ela vai se fazendo pela própria trajetória."

Página 132. "Em meio a isso, dessas circunstâncias que a gente vai conversando, encontramos com pessoas que nos dizem [...]."

Página 20.307. "Quer dizer, a história de vida das pessoas, de qualquer pessoa, ela é sempre uma história que está presente. Por mais que as pessoas digam: “Ah, mas isso não tem nada a ver. Eu me desvencilhei disso ou daquilo..."; em alguma medida, elaborada ou não, a gente sempre carrega a nossa própria história de vida."

Página 753. "A gente vê, às vezes, pessoas que querem fazer pesquisas sobre o ensino de Matemática nos anos iniciais, mas não sabem nada de Pedagogia, não sabem nada de História da 
Educação... E isso é uma coisa complicada! Por outro lado, também, às vezes as pessoas querem fazer um trabalho sobre o ensino de Matemática, mas também não sabem nada de Matemática. Esses trânsitos são, então, necessários."

Página 21.001. "Algo interessante, talvez por essas coisas do acaso [...]" acaso..."

Página 13. "Já tínhamos definido que íamos fazer, mas não sabíamos onde. De novo o

Página 49.821.719. "Quero dizer: é perverso [...], mas, por outro lado, mostrou que havia vida fora $[\ldots] "$

Página 45.121. "E a vida segue... É uma experiência fantástica de uma trajetória de se sentir estrangeiro, uma experiência em que você chega de uma trajetória diferente em um lugar onde as pessoas muitas vezes já têm o seu hábito."

Página 7. "Mas foi quase um acidente isso $[\ldots]$ "

Página 4.524.120.733. "Foi algo assim, a vida foi empurrando mais ou menos para um canto e fui levado para isso."

Página 328.736.

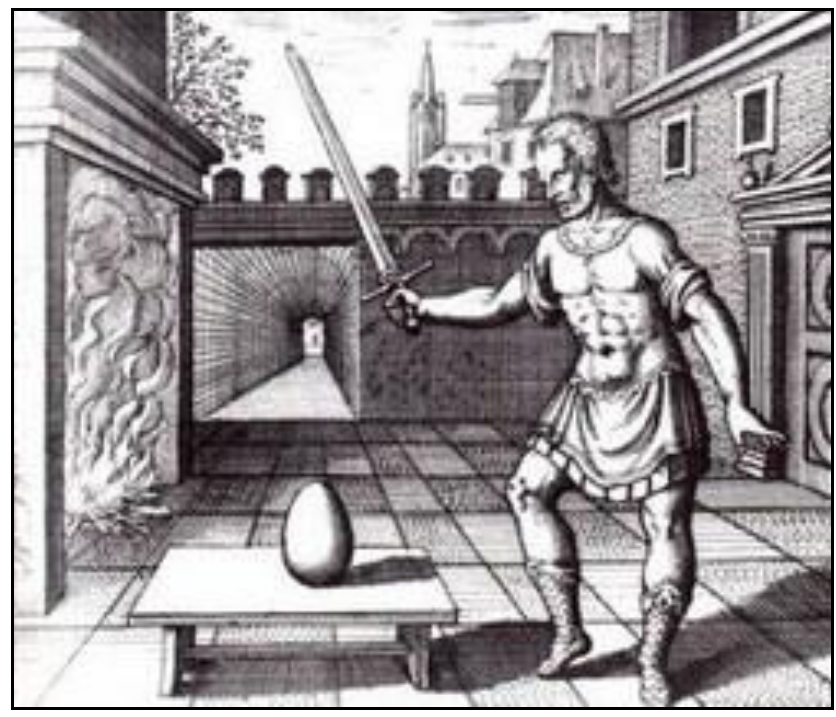

Figura 1 - Michael Meier, Atalanta Fugiens, 1617.

"Há determinadas coisas assim: você escolhe a imagem e a imagem lhe escolhe. Nessa hora, ela traz coisas que lhe são muito significativas, ela the toca. Não é só o que se vê que a imagem lhe traz. Essa imagem traz em si certa impressão, que nos remete à travessia, transformação."

\section{Parte terceira: pensar a efetividade da prática social Educação Matemática}

Uma revista, inequivocamente reconhecida como espaço qualificado de circulação de ideias que competem à Educação Matemática, lança-nos a seguinte proposta: pensar os modos como pesquisas e práticas efetivas têm se imbricado em Educação Matemática. Nesse 
convite, uma palavra chama nossa atenção: efetivas... Como colocar em questão a efetividade de uma prática social? Quando uma prática social é efetiva? Quando não é?

Ao produzir sentidos para a Educação Matemática junto a narrativas de vida de educadores matemáticos ${ }^{5}$, colocando em cena um texto que flerta com a narrativa literária, procuramos problematizar os caminhos pelos quais uma prática social vai sendo desenhada ou, dizendo de outro modo, as estratégias pelas quais se constitui como compromisso na vida de pesquisadores. Entre desenhos e compromissos, entre distintos modos de operar em uma gramática, surgem efetividades que, apesar de seu inacabamento, dizem de uma Educação Matemática.

Como substantivo, a efetividade da Educação Matemática parece estar ligada aos aspectos de sua institucionalização no cenário científico-acadêmico. Trata-se da produção e consolidação de um espaço marcado pelo livre trânsito daqueles que aturaram esses processos, excluindo aqueles que deles, histórico e socialmente, não participaram. A Educação Matemática como substantivo efetiva-se junto à construção de uma comunidade profissional e ao estabelecimento de uma área nas instâncias legitimadas para fazer pesquisa.

Essa institucionalização traz à cena termos como "reconhecimento", "visibilidade", "financiamento". A Educação Matemática parece, então, se efetivar por meio do estabelecimento de um conjunto de atribuições próprias, elementos que apenas a ela competem. Esse conjunto manifesta-se por meio dos mais variados agentes e formas: uma representação que se faz no domínio dos objetos dos quais a Educação Matemática pode produzir um movimento de palavras; nas posições subjetivas que autorizam aqueles que dela podem falar; no campo de produção e subordinação dos discursos por elas produzidos; e nas possibilidades de aplicação e ramificação desses discursos a outros domínios. A efetividade toma, portanto, os contornos da eficiência: fazer algo de maneira certa, mas tendo o dever ou obrigação de fazê-lo. A institucionalização tece uma Educação Matemática com o tecido do dever e, por isso, com as cuidadosas tramas e fios do poder.

Como verbo, a efetividade parece deslocar-se da questão da institucionalização para a do movimento. O que importam são as pessoas, os tempos e os modos que constituem a prática social; em como conjuga elementos para o seu estabelecimento, mesmo que de maneira provisória. A efetividade insinua-se, então, como eficácia: trata-se de um cuidadoso

\footnotetext{
${ }^{5}$ A pesquisa de doutorado de Fernandes (2014), que fundamenta este texto, buscou problematizar os modos de existir da Educação Matemática junto a narrativas de vida de três educadores matemáticos, percorrendo aspectos entre a cientificidade e a historicidade da Educação Matemática como área de pesquisa. Os fragmentos que compõem o "caderno de rascunhos" são recortes das textualizações das entrevistas e trechos dos memoriais dos colaboradores da tese.
} 
processo de escolha, de tomada de decisões, de como as coisas devem ser feitas e pensadas para o cumprimento de determinadas finalidades.

A Educação Matemática atuaria, assim, em meio aos pequenos movimentos, às meticulosas alianças, aos jogos de interesses e necessidades, às articulações para o estabelecimento das finalidades. Sua efetividade estaria pautada na possibilidade, ainda que não materializada em resultados. Trata-se de pensá-la como um verbo operando no infinitivo: cautelosamente, articula elementos para realizar-se, efetivar-se. Conjugam-se modos, tempos, pessoas; vislumbram-se possibilidades. A Educação Matemática será efetiva, pois, enquanto se mantiver latente a sua possibilidade de realização. Uma Educação Matemática de um possível almejado, delicadamente desenhado.

Quando adjetivo, a Educação Matemática efetiva-se de formas não antecipáveis, sequer planejadas ou aspiradas. Por constituir-se nas vias do acidente, entre imposições e acasos, trilhas e desvios, a efetividade da Educação Matemática sequer se aproxima da eficiência ou da eficácia: não é meio nem fim, processo ou produto; mas entre. Um entre que não é pautado na dicotomia, na complementaridade ou na superioridade: trata-se de um trânsito entre o lado de dentro de uma prática social, que opera junto a estratégias que firmam modos de ser, de pensar, de agir e de saber específicos de uma comunidade; e o lado de fora dessa mesma prática social que subverte essas formas de ser, de pensar, de agir, de saber; traçando caminhos não previamente percorridos. Uma Educação Matemática efetivada apenas na variação, na não conformidade, na diferença.

Pensar a efetividade da Educação Matemática é, portanto, atentar-se para seus funcionamentos, para os modos como cria estratégias e táticas para a produção dos saberes, das verdades e dos discursos que direcionam nossas compreensões, falas e legitimidades. Trata-se de evidenciar para que(m) serve este movimento de palavras que constitui uma prática social, denunciando as alianças e os compromissos estabelecidos, as concessões e as subversões cometidas.

Devemos, como educadores matemáticos, propor incansavelmente rascunhos dessa prática social. Traços de compreensões que, ao mesmo tempo em que se permitem e se estabilizam, acusam-se como falsificadores e violentos. Nós, educadores matemáticos, deslocamo-nos entre substantivos, verbos, adjetivos e tantos outros modos, reconhecíveis ou não, de operar junto à Educação Matemática. Nesses modos de operar, efetividades vão sendo fabricadas, inventadas, maquinadas. A atenção a essas efetividades diz, portanto, de uma Educação Matemática. Ou não... 


\section{Encerramento}

Seguiu por tentativas. Buscava fazer com que "muda" operasse como pronome, como numeral, como artigo, como... como... Assim também fez com a Educação Matemática. Fracassos! Por fim, decidiu: "O verão declinava e compreendi que o livro era monstruoso. De nada me serviu concordar que eu era tão monstruoso como ele, via-o com olhos e apalpava-o com os dedos e as unhas. Senti-o como objeto pesado, uma obscena coisa que formava a realidade insana e corrompida. Pensei no fogo, mas temi que a combustão do livro infinito fosse também infinita e capaz de sufocar com fumo o planeta. Lembrei de ter lido que um bosque era o melhor lugar para ocultar uma folha..."

\section{Referências}

BARROS, M. Poesia completa. São Paulo: Leya, 2010.

BORGES, J. L. O livro de areia. In: BORGES, J. L. O livro de areia. São Paulo: Companhia das Letras, 2009. p. 100-105.

FERNANDES, F. S. A quinta história: composições da Educação Matemática como área de pesquisa. 2014. 233f. Tese (Doutorado em Educação Matemática) - Instituto de Geociências e Ciências Exatas, Universidade Estadual Paulista, Rio Claro, 2014.

GARNICA, A. V. M. A experiência do labirinto: metodologia, história oral e educação matemática. São Paulo: Unesp, 2008.

MIGUEL, A.; GARNICA, A. V. M.; IGLIORI, S. B. C.; D’AMBROSIO, U. A educação matemática: breve histórico, ações implementadas e questões sobre sua disciplinarização. Revista Brasileira de Educação, Rio de Janeiro, n. 27, p. 70-93, set./out./nov./dez. 2004.

VIOLA DOS SANTOS, J. R. Legitimidades possíveis para a formação matemática de professores de matemática (Ou: Assim falaram Zaratustras: uma tese para todos e para ninguém). 2012. 355f. Tese (Doutorado em Educação Matemática) - Instituto de Geociências e Ciências Exatas, Universidade Estadual Paulista, Rio Claro, 2012.

Submetido em Abril de 2015. Aprovado em Junho de 2015. 